\title{
Plasma glucagon in diabetes of haemochromatosis: too low or too high?'
}

\author{
W. A. MULLER ${ }^{2}$, M. BERGER, H. J. CÜPPERS, P. BERCHTOLD, \\ G. STROHMEYER, A. E. RENOLD, J. R. HOFSTETTER, AND J.-J. GONVERS
}

From the Institut de Biochimie Clinique, and the Division of Gastroenterology and Nutrition, Department of Médecine, University of Geneva, Geneva; the Policlinique Médicale Universitaire, University of Lausanne, Switzerland; and the Medizinische KlinikE, Universität Düsseldorf, F.R.G.

SUMMARY Glucagon secretion before and during arginine infusions was tested in 11 patients with diabetes associated with haemochromatosis. The results were compared with those obtained in six normal subjects and five patients with haemochromatosis but normal glucose tolerance. The patients with haemochromatosis, regardless of glucose tolerance, exhibited higher levels of plasma immunoreactivity for glucagon (antiserum 30-K) suggesting hyperglucagonaemia. However, additional analysis revealed that a considerable amount of this glucagon immunoreactivity was due to crossreacting material of high molecular weight, the levels of which were significantly higher in patients with idiopathic haemochromatosis. When this was deducted from the total immunoreactivity measured, the resulting values for true glucagon concentrations were similar to those of normal subjects. The data suggest that (1) patients with idiopathic haemochromatosis, whether or not associated with diabetes, exhibit plasma glucagon levels comparable with those of normal subjects; (2) the plasma of the same patients contains significantly more high-molecular-weight substances reacting with glucagon antiserum $30-\mathrm{K}$ than is present in plasma of normal subjects; and (3) 'hyperglucagonaemia' may be erroneously suggested when glucagon is measured with certain antisera reputed to be specific for glucagon.

Diabetes mellitus associated with idiopathic haemochromatosis has, in the past, often been attributed to a destruction of the pancreatic islets by interstitial reaction to iron deposits (Marble and Bailey, 1951; Peterson, 1960; Bothwell and Finch, 1962). If this were the sole pathogenetic mechanism, the secretion of glucagon should also be deficient and low plasma levels of glucagon would be expected. On the other hand, cryptogenic diabetes mellitus is characteristically associated with raised plasma levels of glucagon (Unger et al., 1970; Muller et al., 1970; Buchanan and McCarroll, 1972; Day and Anderson, 1973) and, by analogy, this would argue in favour of raised glucagon levels in patients with haemochromatosis and diabetes. The recent report by Passa et al. (1977) discards the first hypothesis by showing that glucagon secretion is not diminished

${ }^{1}$ Supported by grant no. 3.774 .076 of the Swiss National Science Foundation.

${ }^{2}$ Address for reprint requests: Dr W. A. Muller, Institut de Biochimie Clinıque, Sentier de la Roseraie, CH-1211 Genève 4, Switzerland.

Received for publication 2 October 1978 in eight patients with diabetes and haemochromatosis. In fact, these authors have reported increased levels of plasma glucagon as measured with the glucagon antiserum $30-\mathrm{K}$.

In order to dissociate the relative influence of idiopathic haemochromatosis on glucagon secretion from that of diabetes mellitus in this syndrome, we studied 11 patients, exhibiting both diabetes and haemochromatosis, and compared them with five patients having idiopathic haemochromatosis but normal glucose tolerance and with a non-diabetic control group without haemochromatosis matched for age and sex. Furthermore, analysis for high molecular weight plasma moieties known to crossreact with the glucagon antiserum $30-\mathrm{K}$ (Valverde et al., 1974; Weir et al., 1975; Jaspan and Rubenstein, 1977) has permitted calculation of the 'net' true glucagon concentration of a given plasma sample.

\section{Methods}

PATIENTS

Sixteen patients with idiopathic haemochromatosis. 
were investigated and compared with a control group of six normal subjects. The patients were outpatients or hospitalised in either the Policlinique Médicale Universitaire in Lausanne, Switzerland, or in the Department of Medicine of the University of Düsseldorf, Germany. The diagnosis of haemochromatosis had been established by typical hyperpigmentation, raised serum iron levels (above $1.7 \mathrm{mg} / \mathrm{l})$ and a saturation of total iron binding capacity exceeding $75 \%$ at the time of diagnosis one to 29 years before the study. In all cases, a liver biopsy had been performed, showing on histological examination cirrhosis in 14 and fibrosis in two patients with grade IV iron deposition (Williams, 1968; Dymock et al., 1972). All patients were treated by periodic bleeding. The control subjects were matched by age and sex and reported to the hospital for diseases unrelated to diabetes or other metabolic or gastrointestinal illnesses.

The patients with haemochromatosis were divided into three groups according to their carbohydrate tolerance as assessed by oral glucose tolerance tests (Report of WHO Expert Committee, 1965; Association Suisse du Diabète, 1971): the first group consisted of five patients with a normal tolerance to glucose; the second group comprised seven patients with a pathological tolerance to glucose and included one patient with overt though mild diabetes; the third group included four patients with diabetes requiring insulin treatment. The clinical characteristics of the patients are given in Table 1.

\section{INFUSIONS OF ARGININE}

These were performed after an overnight fast, patients lying in a supine position. Arginine $\mathrm{HCl}$ (pH 6.4) was infused at a rate of $0.45 \mathrm{~g} / \mathrm{kg}$ over 40 minutes in $500 \mathrm{ml}$. At each sampling time, $6 \mathrm{ml}$ of blood was withdrawn from the contralateral antecubital vein into a chilled tube containing $12 \mathrm{mg}$ EDTA $\left(\mathrm{Na}_{2}\right)$, and 3000 KIU Trasylol (Bayer AG, Wuppertal, Germany). After centrifugation of the tubes, the plasma was separated and frozen for storage awaiting measurements of glucose, insulin, and glucagon.

\section{ASSAY PROCEDURES}

Glucose was measured by the glucose-oxidase method (Bergmeyer and Bernt, 1970) (glucose oxidase was provided by Professor F. H. Schmidt, the Boehringer Company, Mannheim, Germany). Iron was determined according to Lauber (1965) and transferrin by nephelometry (Eckman et al., 1970). Insulin and glucagon were determined by immunoassay using charcoal separation (Herbert et al., 1965; Faloona and Unger, 1974). Insulin antiserum was a gift from Dr P. Wright, Indianapolis, Indiana; glucagon antiserum $30-\mathrm{K}$ was donated by Dr R. H. Unger, Dallas, Texas. In order to assess the contribution of the large-molecular type glucagon immunoreactivity, the plasma samples were divided into two parts: one part was diluted 1:2 with assay buffer $(0.2 \mathrm{M}$ glycine, $\mathrm{pH} 8.8$, containing $0.25 \%$ human albumin) and the other part was treated $\mathrm{v} / \mathrm{v}$ by the routine assay charcoal-dextran mixture $(1 \mathrm{~g}$ charcoal, $0.5 \mathrm{~g}$ dextran in $200 \mathrm{ml}$ glycine $0.2 \mathrm{M}, \mathrm{pH} 8.8$ ) and centrifuged. The supernatant and the diluted serums were assayed for IRG in duplicate in a routine assay using $0.2 \mathrm{ml}$ sample in $1.2 \mathrm{ml}$ total volume (Faloona and Unger, 1974). In order to verify the efficiency of charcoal extraction, samples were applied to Biogel P-30 column chromatography as described by Valverde et al. (1974). The columns measured $80 \times 1 \mathrm{~cm}$, the elution buffer was glycine $0.2 \mathrm{M}, \mathrm{pH} 8 \cdot 8$, containing $0.25 \%$ human serum albumin and $500 \mathrm{KIU}$ Trasylol per ml. For calibration of the columns, glucagon-125I and insulin-125I were used. The elution profile of IRG confirmed that charcoal was binding only low molecular weight immunoreactivity (Fig. 1), as described by Weir et al. (1975).

The results were analysed statistically using the $t$ test as described by Snedecor and Cochran (1967). Results are all expressed as mean \pm SEM.

\section{Results}

The plasma concentrations of glucose, insulin, and glucagon, before, during, and after arginine administration are shown in Table 2. As expected, plasma glucose was raised and insulin levels lowered in the patients with glucose intolerance and in the insulin

Table 1 Clinical characteristics of subjects studied

\begin{tabular}{|c|c|c|c|c|c|c|c|c|}
\hline Group & No. & $M / F$ & Age $(y r)$ & Height $(\mathrm{cm})$ & Weight $(\boldsymbol{k g})$ & $\begin{array}{l}\text { Transferrin } \\
\text { ( } \mu \mathrm{mol} / \mathrm{I})\end{array}$ & $\mathrm{Fe}(\mu \mathrm{mol} / l)$ & $\begin{array}{l}\text { Transferrin } \\
\text { saturation (\%) }\end{array}$ \\
\hline $\begin{array}{l}\text { Controls } \\
\text { Haemochromatosis }\end{array}$ & 6 & $4 / 2$ & $51 \pm 3$ & $167 \pm 4$ & $73 \pm 4$ & $30.2 \pm 0.9$ & $14 \cdot 2 \pm 1 \cdot 6$ & $23 \pm 2$ \\
\hline $\begin{array}{l}\text { Normal GTT } \\
\text { Abnormal GTT } \\
\text { Insulin-treated diabetes }\end{array}$ & $\begin{array}{l}5 \\
7 \\
4\end{array}$ & $\begin{array}{l}4 / 1 \\
6 / 1 \\
4 / 0\end{array}$ & $\begin{array}{l}54 \pm 5 \\
47 \pm 3 \\
54 \pm 3\end{array}$ & $\begin{array}{l}171 \pm 5 \\
173 \pm 3 \\
172 \pm 3\end{array}$ & $\begin{array}{l}74 \pm 8 \\
64 \pm 5 \\
72 \pm 4\end{array}$ & $\begin{array}{l}24 \cdot 4 \pm 1 \cdot 0 \\
23 \cdot 7 \pm 1 \cdot 1 \\
21 \cdot 9 \pm 1 \cdot 5\end{array}$ & $\begin{array}{l}25 \cdot 4 \pm 2 \cdot 1 \\
22 \cdot 0 \pm 3 \cdot 4 \\
27 \cdot 8 \pm 6 \cdot 8\end{array}$ & $\begin{array}{l}59 \pm 6 \\
54 \pm 5 \\
60 \pm 9\end{array}$ \\
\hline
\end{tabular}

Patients with idiopathic haemochromatosis were subdivided according to their respective glucose tolerance tests (GTT). Serum iron, transferrin were measured at the time of study and per cent saturation was calculated. Means \pm SEM are given: M/F: males/females. 


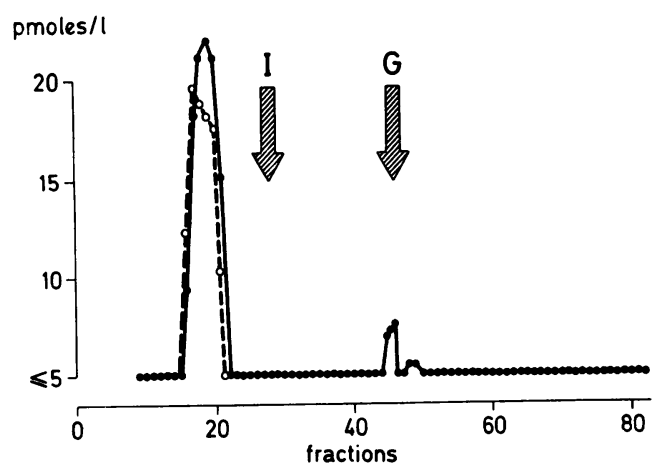

Fig. 1 Glucagon immunoreactivity (30-K) in plasma fractions of a patient with haemochromatosis and diabetes after Biogel P-30 column chromatography. Two millilitres of diluted (1:2) plasma (- -0$)$ or of plasma treated with charcoal $(v / v)(\bigcirc---\bigcirc)$ were applied to Biogel P-30 column chromatography. The fraction volume was $1 \mathrm{ml}$. Recovery: $117 \%$, ○- - $\bigcirc 116 \%$.

treated diabetics. Plasma glucagon, however, was significantly raised at 30 minutes after arginine administration in all patients with idiopathic haemochromatosis, regardless of whether or not they had carbohydrate intolerance (Table 2, Fig. 2A).

In some patients, however, glucagon immunoreactivity was not due exclusively to the $3500 \mathrm{MW}$ fraction eluting with the glucagon-125I marker. Figure 1 shows a representative elution profile of plasma from a patient with both haemochromatosis and insulin-requiring diabetes in whom only $19 \%$ of total plasma glucagon immunoreactivity was due to glucagon. The remaining glucagon immunoreactivity was associated with fractions of high molecular weight. When the plasma was treated with charcoal adsorbing the smaller peptides such as glucagon, the big molecular weight moiety remained and the glucagon peak disappeared (Fig. 1).

Glucagon immunoreactivity was, therefore, measured in all plasma samples after charcoal treatment. Surprisingly, the remaining glucagon immunoreactivity associated with high molecular weight fractions was raised in all three groups of patients with idiopathic haemochromatosis (Fig. 2B): the most pronounced difference occurred in the patients with abnormal glucose tolerance. The third panel (C) of Fig. 2 depicts the calculated values for 'true' plasma glucagon obtained by subtraction of the values after charcoal treatment from those before charcoal exposure-that is, 'total' immunoreactive glucagon. This shows that the patients with idiopathic haemochromatosis exhibit similar plasma levels of 'true' glucagon, as do the normal control subjects (Fig. 2C).

\section{Discussion}

Although the results presented here confirm earlier findings (Gay et al., 1968; Passa et al., 1977) showing that in patients with idiopathic haemochromatosis and diabetes mellitus glucagon secretion is not diminished, they stress the importance of adequate methods in the measurement of plasma glucagon. Using these, it becomes evident that this form of diabetes is not associated with raised plasma levels of glucagon (Fig. 2C) as reported by the authors mentioned. This finding was unexpected as diabetic patients (Unger et al., 1970; Muller et al., 1970; Buchanan and McCarroll, 1972; Day and Anderson, 1973) as well as animals with insulin deficiency (Muller et al., 1971; Frankel et al., 1974) exhibit

Table 2 Effect of arginine $(0.45 \mathrm{~g} / \mathrm{kg} / \mathrm{min}$ i.v.) on concentrations of glucose and immunoreactive glucagon (30-K; total) in plasmas of normal subjects $(N=6)$ and patients with idiopathic haemochromatosis $(I H)$ with either normal glucose tolerance $(G T T)(N=5)$, pathological glucose tolerance $(N=7)$, or treated $(R x)$ with insulin $(N=4)$

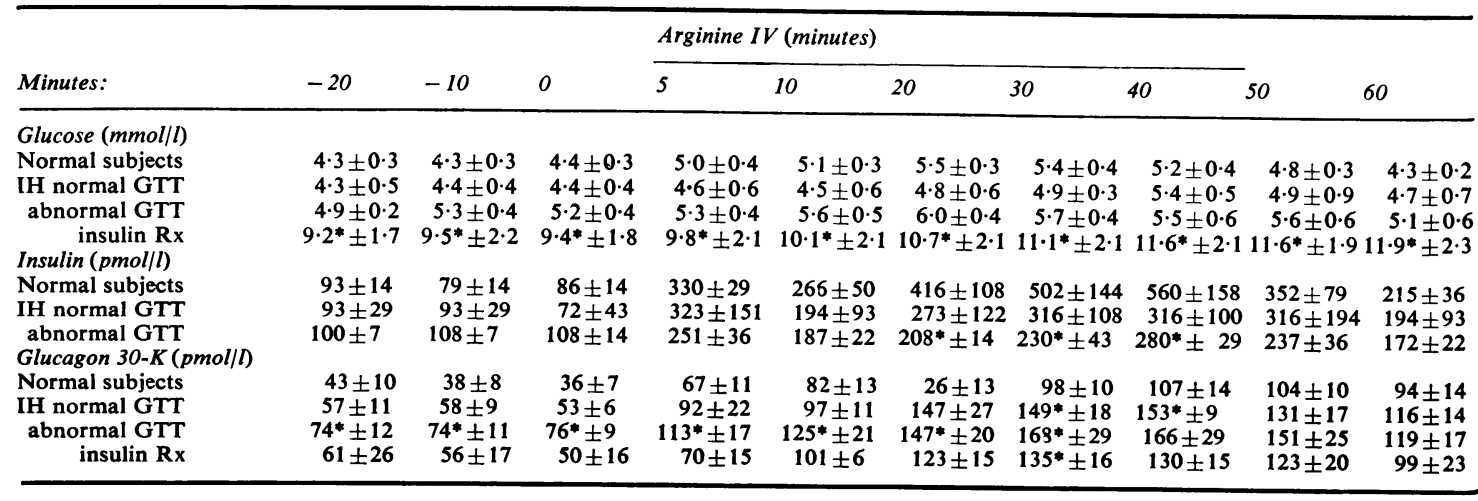

Means \pm SEM are given. The asterisks indicate significant differences $(P<0.05)$ when compared with the normal control group. 

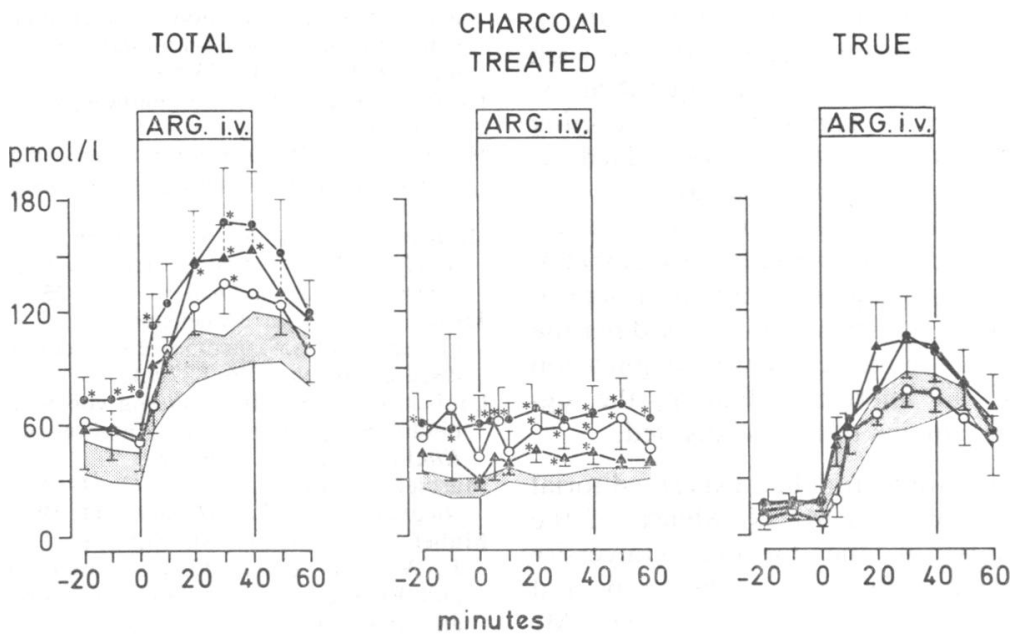

A

Fig. 2 Effects of intravenous arginine (450 $\mathrm{mg} / \mathrm{kg} / 40 \mathrm{~min}$ ) on immunoreactive glucagon (IRG, antiserum 30-K) in plasma of patients with idiopathic haemochromatosis associated with normal glucose tolerance $(\mathbf{\Delta})$, abnormal glucose tolerance (O), or insulin-requiring diabetes $(\bigcirc)$. The shaded area represents a normal control group (mean $\pm S E M)$. A: total IRG, B: IRG left after charcoal treatment of the plasma, $C$ : the calculated values for true glucagon $(A-B=$ $C)$. Asterisks indicate significant differences $(\mathrm{P}<0.05)$ between patient groups and the normal control group.

raised plasma concentrations of glucagon. Accordingly, those of our patients treated with insulin would have been expected to have raised glucagon levels. The fact that this was not the case suggests the possibility of a partial alpha-cell destruction by haemochromatosis. A possible argument against this is the fact that the alpha-cell destruction was only just sufficient to reduce plasma glucagon to levels indistinguishable from a normal control group. Histological examination of islets of patients with idiopathic haemochromatosis were, in fact, reported to have iron deposits exclusively in the beta-cells (Hartroft, 1956). On the other hand, the pancreatectomised patients demonstrate that diabetes mellitus does not require (Unger and Orci, 1975 ) the presence of glucagon (Barnes and Bloom, 1976; Muller et al., 1979). Therefore, hyperglucagonaemia called 'characteristic' for diabetes mellitus (Unger, 1976) might not necessarily be present in all forms of diabetes.

The data show that patients with idiopathic haemochromatosis exhibit raised plasma levels of high molecular weight glucagon immunoreactivity (Figs 1 and 2). This factor of molecular weight greater than 30000 (Weir et al., 1975), cross-reacting with glucagon antiserum 30-K has been called 'big plasma glucagon' or 'BPG' (Valverde et al., 1974).
It is as yet not well characterised: the fact that trypsin treatment can convert part of it into immunoreactive material close to the size of glucagon (Valverde et al., 1974; Jaspan and Rubenstein, 1977) suggests that part of BPG might represent glucagon bound to a carrier. It might, on the other hand, represent a pre-pro-hormone or cross-reacting material independent on glucagon or a combination of these. Srikant et al. (1976) found that tissueextracted BPG could induce glucose release from rat livers perfused in vitro. One might speculate that the increased $\gamma$-globulin in the serum of some of our patients was related to the increased plasma levels of BPG. In a patient with agammaglobulinaemia, absence of 'large molecular weight glucagon' has been reported (Von Schenk, 1977). An attempt, however, to correlate plasma BPG in our patients with the respective plasma tranferrin concentrations was negative. Similarly, it is doubtful whether the presence or absence of diabetes, or its severity, in the patients with idiopathic haemochromatosis had any influence on the amount of BPG, as between these groups no significant difference was detected (Fig. 2B).

These results confirm that measurements of plasma glucagon using antiserum $30-\mathrm{K}$ or similar antisera can be misleading (Weir et al., 1975; 
Valverde et al., 1974; Jaspan and Rubenstein, 1977). States of hyperglucagonaemia diagnosed with such an antiserum have, therefore, to be qualified by methods which serve to eliminate cross-reacting high-molecular-weight substances before (Heding, 1971) or after the glucagon immunoassay.

In conclusion, patients with idiopathic haemochromatosis, whether or not associated with diabetes, have plasma levels of glucagon within the range of normal controls. These patients exhibit raised plasma concentrations of a big-molecular-weight glucagon immunoreactivity, an intcresting finding, the significance of which remains to be investigated.

We thank Mrs J. Gunn for her expert editorial assistance, Dr M. Roth and Mr N. Mensi, of the Central Laboratory of the Geneva University Hospital, for having determined the iron and transferrin levels in our patients' plasma, $\mathrm{Mr}$ Asllan Gijinovci for excellent technical assistance, and the nurses at the University Hospitals in Lausanne and Düsseldorf for the help they gave in carrying out the infusion studies in our patients.

\section{References}

Association Suisse du Diabète, Société Suisse de Chimie Clinique (1971). Nouvelles Directives pour le Diagnostic du Diabete. Service Scientifique, Roche; Basle.

Barnes, A. J., and Bloom, S. R. (1976). Pancreatectomised man: a model for diabetes without glucagon. Lancet, 1, 219-221.

Bergmeyer, H. U., and Bernt, E. (1970). D-glucose Bestimmung mit Glukose-Oxydase und Reoxydase. In Methoden der Enzymatischen Analyse, p. 1172. Edited by H. U. Bergmeyer. Verlag Chemie: Weinheim/Bergstrasse.

Bothwell, T. H., and Finch, C. A. (1962). Iron Metabolism, p. 393. Little Brown: Boston.

Buchanan, K. D., and McCarroll, A. M. (1972). Abnormalities of glucagon metabolism in untreated diabetes mellitus. Lancet, 2, 1394-1395.

Day, J. L., and Anderson, J. (1973). Abnormalities of glucagon metabolism in diabetes mellitus. Clinical Endocrinology, 2, 211-217.

Dymock, I. W., Cassar, J., Pyke, D. A., Oakley, W. G., and Williams, R. (1972). Observations on the pathogenesis, complications and treatment of diabetes in 115 cases of haemochromatosis. American Journal of Medicine, 52, 203-210.

Eckman, I. Robbins, J. B., van den Hamer, C. J. A., Lentz, J., and Scheinberg, I. H. (1970). Automation of a quantitative immunochemical microanalysis of human serum transferrin: a model system. Clinical Chemistry, 16, 558-561.

Faloona, G. R., and Unger, R. H. (1974). Glucagon. In Methods of Hormone Radioimmunoassay, p. 317. Edited by B. M. Jaffe, and H. R. Behrman. Academic Press: New York.

Frankel, B. J., Gerich, J. E., Hagura, R., Franska, R. E., Gerritsen, G. M., and Grodsky, G. M. (1974). Abnormal secretion of insulin and glucagon by the in-vitro perfused pancreas of the genetically diabetic Chinese Hamster. Journal of Clinical Investigation, 53, 1647-1656.

Gay, J., Tchobroutsky, G., Rosselin, G., Assan R., Dolais J., Freychet, P., and Dérot. M. (1968). Étude de huit cas d'hémochromatose primitive comportant en particulier le dosage radio-immunologique plasmatique des hormones somatotrope, folliculo-stimulante et du glucagon. Pathologie et Biologie, 16, 53-60.

Hartroft, W. S. (1956). Islet pathology in diabetes. Diabetes, 5, 98-104.

Heding. L. G. (1971). Radioimmunological determination of pancreatic and gut glucagon in plasma. Diabetologia, 7 , 10-19.

Herbert, V., Lau K. S. Gottlieb, C. W., and Bleicher, S. H. (1965). Coated charcoal immunoassay of insulin. Journal of Clinical Endocrinology, 25, 1375-1384

Jaspan, J. B., and Rubenstein, A. H. (1977). Circulating glucagon. Plasma profiles and metabolism in health and disease. Diabetes, 26, 887-902.

Lauber, K. (1965). Bestimmung von Serumeisen und Eisenbindungskapazität ohne Enteiweissung. Zeitschrift für Klinische Chemie, 3, 96-99.

Marble, A., and Bailey, C. C. (1951). Hemochromatosis. American Journal of Medicine, 11, 590-599.

Muller, W. A., Berger, M., Suter, P., Cüppers, H. J., Reiter, J., Wyss, T., Berchtold, P., Schmidt, F. H., Assal, J. P., and Renold, A. E. (1979). Glucagon immunoreactivities and amino acid profile in plasma of duodenopancreaytectomized patients. Journal of Clinical Investigation, in press.

Muller, W. A., Faloona, G. R., Aguilar-Parada, E., and Unger, R. H. (1970). Abnormal alpha-cell function in diabetes. Response to carbohydrate and protein ingestion. New England Journal of Medicine, 283, 107-115.

Muller, W. A., Faloona, G. R.. and Unger R. H. (1971). The effect of experimental insulin deficiency on glucagon secretion. Journal of Clinical Investigation, 50, 1992-1999.

Passa, P., Luyckx, A. S., Carpentier, J. L., Lefebvre, P. J., and Canivet, J. (1977). Glucagon secretion in diabetic patients with idiopathic haemochromatosis. Diabetologia. 13, 509-513.

Peterson, R. E. (1960). In The Metabolic Basis of Inherited Disease, p. 839. Edited by J. B. Stanbury, J. B. Wyngaarden, and D. S. Fredrickson. Blakiston Division, McGraw-Hill: New York.

Report of WHO Expert Committee (1965). Diabetes mellitus. WHO Technical Report Series, 310.

Snedecor, G. W., and Cochran, W. G. (1967). Statistical Methods. Iowa State University Press: Ames, Iowa.

Srikant, C. B., McCorkle, K., and Unger, R. H. (1976). Characteristics of tissue IRGs in the dog. Metabolism, 25 , 1403-1404.

Unger, R. H. (1976). Diabetes and the alpha-cell. Diabetes, 25, 136-151.

Unger, R. H., Aguilar-Parada, E., Müller, W. A., and Eisentraut, A. M. (1970). Studies of pancreatic alpha-cell function in normal and diabetic subjects. Journal of Clinical Investigation, 49, 837-848.

Unger, R. H., and Orci, L. (1975). The essential role of glucagon in the pathogenesis of the endogenous hyperglyclemia of diabetes mellitus. Lancet, 1, 14-15.

Valverde, I., Villanueva, M. L., Lozano, I., and Marco, J. (1974). Presence of glucagon immunoreactivity in the globulin fraction of human plasma ('big plasma glucagon'). Journal of Clinical Endocrinology and Metabolism, 39, 1090-1098.

Von Schenk, H. (1977). Production and characterization of an antiserum against pancreatic glucagon. Clinica Chimica Acta, 80, 455-463.

Weir, G. C., Knowlton, S. D., and Martin, D. B. (1975). High molecular weight glucagon-like immunoreactivity in plasma. Journal of Clinical Endocrinology and Metabolism, 40, 296-302.

Williams, R. (1968). Iron metabolism. In Recent Advances in Medicine, p. 188. Edited by D. N. Baron, N. Compston, and A. M. Dawson. Churchill: London. 